\title{
Teacher Perceptions of Climate, Motivation, and Self-Efficacy: Is There Really a Connection
}

\author{
Shemon J Reaves ${ }^{1}$, Jeffry Allen Cozzens ${ }^{2}$ \\ ${ }^{1}$ Jackson-Madison County Schools, USA \\ ${ }^{2}$ Freed-Hardeman University, USA \\ Correspondence: Jeffry Allen Cozzens, Freed-Hardeman University, USA.
}

Received: August 26, 2018

doi:10.11114/jets.v6i12.3566
Accepted: October 6, $2018 \quad$ Online Published: October 12, 2018

URL: https://doi.org/10.11114/jets.v6i12.3566

\begin{abstract}
This study investigated if correlations existed between teachers' perceptions of elements of a safe and supportive school climate/working environment in regards to teachers' intrinsic motivation and self-efficacy beliefs. Additionally, it examined the degree of significance when teachers feel safe and supported versus those that do not. Finally, it investigated which of the four elements has the greatest impact on intrinsic motivation and self-efficacy through the lens of educators to improve teaching, teacher retention, and job satisfaction. Survey data were collected from certified teachers in West Tennessee school districts. The responses to the Safe and Supportive School Questionnaire and Attitude Toward Teaching Survey provided quantitative data for analyses. A series of independent samples $t$-tests, liner regressions, and Spearman correlations revealed strong positive correlation existed between a number of the four elements and intrinsic motivation and self-efficacy. Additionally, it revealed teachers have significantly higher intrinsic motivation and self-efficacy in safe and supportive schools. Conclusions of this study and recommendations are outlined in this paper.
\end{abstract}

Keywords: school climate, culture, teachers ${ }^{e e}$ perceptions, motivation, self-efficacy, instructional leadership, safety, education reform

\section{Introduction}

The focus of this research is to identify elements that teachers perceived as significant to their connection with school climate and motivational factors at the workplace. Inman and Marlow (2004) demonstrated in their study of teachers' intrinsic and extrinsic motivation that a relationship existed between teacher motivation and job satisfaction in the workplace. Understanding these factors is critical to the sustainability of a healthy school system as an organization, as well as retention of teachers as pillars upon which teaching and learning are built. Earlier research suggests that positive school climate is associated with stronger academic performance, higher graduation rates, decreased incidences of violence and increased teacher retention (Clifford, Menon, Condon, \& Hornung; 2012; Gangi, 2010; Haggerty, Elgin, \& Woodley, 2010). Previous research also proposes that a positive school climate makes school an appealing, satisfying, and meaningful environment in which both adults and youth care to spend a substantial portion of their time (Connolly, Pryseski, \& Smith, 2014). According to Peterson, (as cited in Cabansag, 2013), many sociologists believe that current school environments are reward-scarce settings for professionals and often seem to work against teachers' best efforts to grow professionally and improve job satisfaction. Furthermore, a report from the National School Climate Center in February 2013 entitled; School Climate and Shared Leadership contended that the creation of a positive school climate, teacher buy-in, and a safe and supportive work environment were the pillars upon which retention of teachers is built, and the foundation upon which teaching and learning is realized (Hughes \& Pickeral, 2013).

The National Center for Education Statistics (2003) claimed that due to negative school climates, unsafe work environments, and negative teachers' perceptions, 621,000 elementary and secondary teachers left the teaching workforce to pursue employment in fields other than education. Additionally, based on data from the 2000-2001 Teacher Follow-up Surveys, 25.5\% of novice teachers left the teaching profession after three years, and 32\% of teachers left after four years due to hostile school climates, unsupportive work environments and negative perceptions of their school (National Center for Education Statistics, 2003). These reports paint a dim picture for the future health of today's school systems, recruitment of highly qualified educators and retention of teachers. 
It is vital to the success of $21^{\text {st }}$ Century schools that educational leaders and policy makers discover elements that influence positive school climates/work environments, teachers' perceptions of the workplace, and teachers' motivational factors (Green, 2013). As a result, they will be better equipped to increase teachers' job satisfaction and promote teacher retention. According to Canter and Canter, 2010, Clark and Reaves, 2014, Parrett and Budge, 2012, an important element needed to create a positive school climate and safe and supportive work environment is ensuring the safety of faculty and staff. They further agreed when stakeholders pose a sense of security, positive trusting relationships can flourish among faculty, staff members and students within the school. The Department of Homeland Security (2016) asserted that many Americans feel schools should be a place where all stakeholders feel welcome and safe. In fact, schools should be safer than the home. Hughes and Pickeral (2013) revealed that it is imperative that the safety of the students and faculty members, the safety of the school buildings, and its surroundings are top priorities when establishing and maintaining a safe and supportive school. Bishop, Cardichon, and Roc, (2014), added elements that influence positive school climates, safe and supportive work environments, and teachers' perceptions must be considered as means of responding to teacher attrition and teacher shortages in school systems.

\subsection{Background of Study}

Based on the research of Hoy (1990), the concept of climate and culture provided a springboard for future research of the school as a social organization and work place in its own right. Clark and Reaves (2014) and Sandiker (2003) stated that before students can learn or teachers can teach, schools must be safe. The 1980s, 1990s, and 2000s witnessed their share of violent incidents that were indicative of the types of negative school climates that lead to teacher dissatisfaction and feelings of insecurity. Tims and Mecham (1998) recalled an event that occurred on May 21, 1988, at Thurston High School in Springfield Oregon when a 15-year old boy entered the cafeteria and opened fire on 400 individuals. A 17 -year old boy was shot and killed, while 23 other students were wounded. The incident created an environment that petrified the parents, students, and faculty members. As a result, some of the teachers fled the school and never returned. On October 1, 1997, in Pearl Mississippi, a middle school boy opened fire during school hours, killing two students and wounding several others. On December 1, 1997, in West Paducah Kentucky, a 14-year old boy walked into a classroom, shot, and killed eight students during daily prayer. As a result, staff members were afraid, and many contemplated leaving the school because they felt that it was unsafe (Associated Press, 1997). On March 24, 1998, in Jonesboro Arkansas, two boys fired at innocent students, killing four girls and wounding 9 other students at Westside Middle School (Davis, 1998). According to a report published by the National School Safety Center (2006), from 1992- 2004, serious violence, victimization of teachers, and bullying of students were pervasive and deplorable. These trends accelerated the rate of teacher attrition and slowed down the acquisition of qualified teachers in the school districts.

According to Canter \& Canter (2001) and Kohn (2006), school officials are accepting their roles and responsibilities to offer a framework for schools to implement a safe and supportive educational environment for all students and staff. Schools are drafting new policies and procedures to ensure educational access for all students as well as promoting the well-being of students who exhibit inappropriate behaviors at school (Birkland \& Lawrence 2009). School officials are implementing new policies and procedures because of Federal statutes such as The Individual with Disabilities Education Act (IDEA), Public Law PL 94-142 (Education for All Handicapped Children [EHA], 1975) and Public Law PL 107-110 (No Child Left Behind [NCLB], 2002). Clark and Reaves (2014), suggested refining and implementing policies and procedures school officials will be able to make better data-driven decisions, properly align programs, and ensure that they are effective.

The federal government began safety concerns in public schools and on college campuses in the United States of America in the 1990s by introducing the idea of interactive training after the shooting at Columbine. In the 1990s the Gun-Free Schools Act (GFSA) of 1994 (P.L. 103-227) was passed in Congress. It is a federal United States law that makes it illegal for any unauthorized person to possess a firearm at a place that he or she knows or has reasonable cause to believe is a school zone as defined by the U.S.C. $§ 921$ (a) (25). It gained popularity after school safety and fears were heightened by increase of school shooting plots by currently students, former students, and disgruntled employees. Not to be confused with the Gun-Free School Zones Act (GFSZA) of 1990, the Gun-Free Schools Act was a part of the Improving America's Schools Act of 1994 (IASA) that required school districts to adopt a gun-free position in exchange for federal funds. Shah (2012) stated that more than 25,000 students have been expelled from schools throughout the United States for violating the Gun-Free Schools Act.

Tennessee was one of eleven states that qualified to participate in Safe and Supportive Schools (S3) efforts (United States Department of Education, 2010). This federal program was developed to enhance school safety and support the school's operations, physical, and fiscal management, Additionally, the Safe and Supportive Schools (S3) Program sought to develop a system that collects and synthesizes building-level student, parent, and teacher perceptions of engagement, safety and environment to provide an actionable measurement of conditions for learning.

Ingersoll (2001) used data extracted from the Schools and Staffing Survey and National Center for Education Statistics 
to infer that teachers nationwide were leaving the profession due to the dissatisfaction of their working conditions and safety concerns. Ingersoll also revealed that since the 1980s, teacher shortages have been on the rise due to teachers leaving the profession. According to Hunt and Carroll, (as sited in Johnson, 2014), the trend in turnover rate for teachers is consistently higher than many existing occupations in the nation. This trend of teacher turnover is symptomatic of the inability to maintain high-quality teachers in the schools.

Boe, Cooke, and Sunderland (2008) claimed that negative school climates stimulated a national teacher turnover rate as high as 22-23\% during the 1990s. Luekens, Lyter, Fox, and Chandler (2004) used data obtained from the 2000-2001 Teacher Follow-up Survey to demonstrate that the teachers' attrition rate increased by $50 \%$ since 1990 and the turnover rate rose 16.8\% during 2004-2005 school year. Hunt and Carroll (2002) found that in the 1999-2000 school year, 534,861 teachers were hired in school districts, but by the end of the school year, 539,778 decided to leave the educational profession to pursue other career paths due to hostile school climates. Ingersoll and Smith (2003) suggested that the loss of teachers in educational classrooms creates a desolate situation for a school system and desolation leads to damage of the school and the learning process for stakeholders. Ingersoll (2003b) claimed that the greater demand for teachers in the 1980s, 1990s, and 2000s, the loss of teachers in school districts due to hostile school climates and dissatisfaction of their working environments does not bode too well for the current state of education in our communities.

During the past three decades, research has expanded and is being conducted by more educators and educational researchers (Fuernick, 2007). As a result, several patterns emerged explaining why teachers were leaving school districts in the United States. Loeb, Darling-Hammond, and Luczak (2005) found that the greatest predictor of teachers leaving a school is the teacher's perceptions of working conditions in the school. According to Ingersoll (2003b) evidence citing why teachers are leaving schools, point to factors of working conditions such as teachers' loss of motivation to work, lack of encouragement from the leadership, and lack of collegiality. Liu and Meyer (2005) states that," low teacher salary is also a contributing factor to teachers leaving the educational profession and paints a negative perception of the profession at large." Hirsch (2004) revealed that as a result of teachers leaving the profession, school districts attempted to lure prospective qualified teachers in by offering signing bonuses and offered extra incentive payments to teachers already employed. Although the luring of teachers into the profession with better pay incentives was a strategic management strategy for school districts, it was a short-lived strategy. It did not have longevity because teachers continued to leave the profession and an increase of teacher shortage persisted as teachers sought careers elsewhere. Educational leaders and researchers are still attempting to identify factors that lead to the creation of hostile school climates, unwelcoming perceptions, and teacher hopelessness and lack of empowerment.

Ingersoll (2001) found that 33\% of novice teachers left schools within the first three years and $46 \%$ of them left schools after five years in the profession. Darling-Hammond (2007) found that teachers who enter the teaching profession from an alternative path left schools with a higher attrition rate of $40-60 \%$ after three years of entering the profession. Darling-Hammond also revealed negative school climates, unwelcoming perceptions, and lack of teacher empowerment contributed to a higher rate of attrition. Ingersoll and Smith (2003) claimed nationwide statistics have shown 15\% of new teachers leave teaching within their first year, and another 15\% changed schools each year in the school district. According to Canter and Canter, (2001) and Ingersoll and Smith (2003), hostile school climates, unwelcoming perceptions, and lack of motivation forced teachers to leave the profession.

Inman and Marlow's (2004) study revealed that school cultures that promoted teacher empowerment and provided incentives, increased teachers' intrinsic and extrinsic motivation to stay at school and continue to want to teach. Conversely, school cultures that promoted hostilities toward teachers experienced educators leaving the schools to seek out other fields that were friendlier and accommodated their needs. Johnson and Birkeland (2003) found that school culture was the determinant of teacher intrinsic motivation and job satisfaction. According to Canter \& Canter (2001) and Kohn (2006), school officials are accepting their roles and responsibilities to offer a framework for schools to develop, implement, and maintain a safe and supportive educational environment that welcomes, empowers, and motivates all stakeholders.

The challenge to provide positive school climates and safe and supportive working environments affects all school districts in the United States. As a result, these critical issues need to be resolved to ensure highly qualified teachers can teach and learners can effectively learn. Clements (2000) notes that principals must provide clear expectations, establish a support system for teachers, and hold staff members accountable to keep them motivated to teach. He indicates this could be done by creating a positive school climate and positive working environment, in which they feel safe, empowered, and respected.

\subsection{Statement of Problem}

There is a gap in knowledge that establishes the extent school climate and teachers' perceptions of the school as workplace influence teacher's job satisfaction, safety, retention, attrition, and motivation. Additionally, there is a gap in 
identifying to what extent working conditions influence teachers' perceptions of their workplace as well as the correlation of motivation and self-efficacy. There is a problem with retaining teachers with high self-efficacy in schools that are perceived to be unwelcoming for all stakeholders. However, evidence extracted from the National Center for Education Statistics obtained from the 1994-1995 Teacher Follow-up Survey showed that after five years, between $40-50 \%$ of beginning teachers left the profession due to negative school climate and lack of teacher encouragement by the leadership (Ingersoll \& Smith, 2003). Data taken from the National Commission on Teaching and America's Future (2003) revealed that in 1999-2000; 232,000 new and reentering teachers were hired. One year later, 287,000 left teaching for professions other than teaching, which were 55,000 more teachers leaving the teaching profession than had been previously hired. The National Commission on Teaching and America's Future goes on to say, the reasons for leaving the teaching profession were attributed to negative school climates, negative perceptions of the working environment, and a feeling of lack of support.

Clark and Reaves (2014), states monitoring and analyzing data should be an ongoing process. As a result, school officials will be able to make better data-driven decisions, properly align programs, and ensure that implemented programs are effective. In addition, their study indicates, positive school climates, positive teacher perceptions of the school, teacher job satisfaction, and motivation should be high priority action steps aimed at keeping teachers in school districts.

The National Commission on Teaching and America's Future (2003) revealed when teachers were asked why they leave their jobs, working conditions topped the list. Darling-Hammond (2003) found that working conditions played a vital role in teachers' decisions to leave or stay in the profession. In addition, teachers attributed their responses to experiences with positive school climates, feelings of safety and support, and job satisfaction as reasons they continued to withstand the demanding task as an educator. It is expected that future research will reveal ways to create and sustain positive school climates, positive teachers' perceptions of a school, increase teachers' job satisfaction, and propel the motivation of teachers, aiding educational leaders and policymakers in making informed decisions (Boe, Cooke, \& Sunderland, 2008).

\subsection{Purpose of Study}

The purpose of this study is to gather knowledge from teachers related to perceptions of positive school climates, motivational factors, and self-efficacy. This is important because there is a gap in literature regarding the correlation of school climate, teacher perceptions of their working environment, and self-efficacy. The research method used in this study was correlational in nature and data were collected through online surveys administered to certified teachers in West Tennessee school districts. The results provided information in regards to the perceptions of teachers as professionals at the workplace (Weiss, 1999). It also offered an understanding of the aforementioned variables in order to; develop and sustain positive school climates, improve perceptions of schools, and increase motivation and self-efficacy.

\subsection{Significance of Study}

According to Hunt and Carroll (2002) the number of teachers leaving the profession due to hostile school climates, unwelcoming school cultures, and lack of motivation was three times higher than teachers retiring. Previous research also suggests that working conditions that aid in promoting the success of teachers such as collegial environment and supportive leaders are significant factors to attract, motivate, and sustain teachers to the profession (Frase, 1992; Luekens et al., 2004; Ingersoll, 2001). Many current researchers have emphasized the need to address school climate, school culture, and teacher motivation in order to bring about understanding and effective change (Futernick, 2007; Liu $\&$ Meyer, 2005). Research that provides information to inform educators, policy makers, administrators, state department of education officers, and existing stakeholders about workplace environments will aid in the preparation of making the workplace a safer and more secure environment where all stakeholders feel at ease (Anhorn, 2008; Jones \& Jones, 2013).

Grissmer and Kirby (1997) and Good and Brophy (2008) identified that public schools in the United States have a cadre of teachers that are more educated and experienced than ever before. These teachers, however, are facing some of the most hostile school climates and unwelcoming school cultures of any nation. Schools are experiencing instances of firearm possession, violence, and bullying that is jeopardizing the safety and security of these well-educated and experienced teachers (Johnson \& Birkeland, 2003; Jones \& Jones, 2013). Teachers are employees who work best in a stable and satisfying work environment (Green, 2013; Marzano, Marzano, \& Pickering, 2003). Positive school climates and positive school cultures are the two strategic management approaches school leaders must implement to retain the cadre of educated and experienced teachers in the United States to ensure the sustainability and survival of schools as organizations (Epistein, \& Buhovac, 2014; Green, 2013). So this study will explore the connection of teacher's perceptions, motivation and self-efficacy. 


\subsection{Relationship to Prior Research}

The National School Safety Center (2013) suggested that assessing the perceptions of school climate, educators and education agencies can identify key issues in need of reform. Once needs are identified, data from school climate assessments can be used to set goals and priorities and choose programmatic interventions. Additionally, findings from the school climate assessment used by the school can identify areas where students, staff, and parents view climate in similar or dissimilar ways. Clark and Reaves (2014) proposed measuring school climate data is vital for sustainability of today's schools. Furthermore, the data should be used to implement intervention goals as well as track progress toward accomplishing those goals. Moreover, this research answered the call of Anhorn, 2008, as well as Jones, and Jones, 2013. Their previous study suggested that future research providing information to inform educators, policy makers, administrators, state department of education officers, and existing stakeholders about workplace environments will aid in the preparation of making the workplace a safer and more secure environment where teachers feel at home and can empower students.

The current research supported several theories such as Pavlov's classical conditioning theory, Bandura's self-efficacy and social cognitive theories, and Maslow's hierarchy of needs theory. This research validated Pavlov's classical conditioning theory showing it impacts school climate and culture. Schools are striving to find methods to motivate employees to adopt behaviors that are consistent with organizational goals and increased productivity to have highly motivated employees with a sense of high self-efficacy (James, 2013). Data from James' study indicated that several schools increased teachers' levels of motivation, emotionality, planning, commitment, stability, and competence required for classroom management. Catlett (2015) also supported Pavlov's classical conditioning theory by putting parameters in place to condition a desired behavior. Catlett's research supported the notion that positive school climates can create positive attitudes and relationships among teachers. The data from the current study revealed that Positive staff relationships emerged from a safe and supportive school climate.

The research also reinforces Bandura's self-efficacy and social cognitive theories. It shows that Bandura's theories outline the connection of setting a positive school culture to the increase of self-efficacy and motivation. Bandura's social cognitive theory posits that the development of an individual's behavior is linked to self-efficacy, social structural factors, outcome expectations, and goals. The theory's core concept is that individuals can gain knowledge by directly observing others within the context of social interactions, experiences, and outside media influences (Bandura, 2002). Maddux, Sherer, and Rogers (1982), studied relationships between self-efficacy and outcome expectancies. They defined outcome expectancies as beliefs about the consequences of one's action that are influenced by physical, social and self-evaluative factors. Bandura (2002, p.4), stated that, "outcome expectancies along with self-efficacy influence goal setting and goal pursuit." Data revealed Bandura's theories are prevalent in this research as well. It discovered that the element that had the greatest impact on a teacher's intrinsic motivation was clear expectation and parameters, while active monitoring had the greatest on a teacher's self-efficacy.

Maslow's hierarchy of needs theory is shown to have a connection with motivation and the personality theory. Maslow contented that a relationship exists between individual motivation and performance in any given organization. According to Dorer and Mahoney (2006), corporations and schools' workplaces exemplified environments where individual motivation is essential to stimulate productivity and success of an organization. Curry (1993) contributed an increase in self-efficacy and motivation included the setting, performance feedback, and social comparison. Koltko-Rivera (2006) noted that Maslow's self-efficacy and motivational theories have made major contributions to teaching and classroom management. This research underpinned Maslow's theories by showing when teachers' needs are met, they can be more effective and efficient. For example, when teachers feel safe and supported, appreciated, and that they belong within the organization, they are more apt to have higher intrinsic motivation and self-efficacy beliefs. These theories mentioned above were the fundamental frameworks for this study and are used to support the findings that there is a connection between a teacher's perceptions, climate and motivation.

\subsection{Assumptions}

Assumptions that guided the research during the planning and analysis of the study are as follows:

- Teachers' perceptions of the workplace are the pillars upon which teachers and schools can enhance the current school climate and culture to support the sustainability of the school as an organization (Epistein \& Buhovac, 2014).

- Teachers' perceptions of working conditions are the pivotal factors for creating and sustaining the vision of the school and implementing strategic management policies that keep teachers in the school (Good \& Brophy, 2008; Green, 2013; Werbach, 2009). Rather, the impact of policy on educator's current perceptions. Ultimately, the school climate/working conditions plays a vital role in the perceptions of teachers and impacts their ability to effectively perform job tasks. 
- Teachers' perceptions of the school, school climate, and staff relationship are strategic management approaches that can be incorporated into the professional development of teachers to support the school's sustainability as an organization and maintain teachers' self-efficacy level and motivation. (Epistein \& Buhovac, 2014; Werbach, 2009).

- Teachers' perceptions of self-efficacy can be incorporated into school climate to move the school in a positive and productive direction for all stakeholders which impacts the climate and culture. (Bandura, 1997; Green, 2013; Marzano, Marzano, \& Pickering, 2003).

- Teachers' perceptions of the workplace can establish the foundation upon which creativity, agility, and innovation to move the school in a positive direction in midst of negativity while increasing teachers' self-efficacy level and motivation (Eoyang, 2009; Epistein \& Buhovac, 2014; Hughes, Beatty, \& Dinwoodie, 2014; Wheatley, 2006).

- Teachers' perceptions of job satisfaction can be used to galvanize and implement strategic management tactics by the school leadership to develop positive school climate and establish a welcoming school culture. In which will help teachers make grounded decisions on whether to remain in the profession or pursue other career opportunities (Epistein \& Buhovac, 2014; Marzano, Marzano, \& Pickering, 2003).

\section{Method}

\subsection{Research Design}

The purpose of this research study was to gather knowledge from teachers related to elements of safe and supportive schools, teachers' perceptions of positive school climates, motivation, and self-efficacy. When this knowledge is gathered, it will be examined to see if a correlation exists between at teacher's perception, motivation, and self-efficacy. The study sought to address the following research questions:

Q1. To what extent do teachers perceive that their schools exhibit specific elements of a safe and supportive school climate (i.e. positive staff relationships, accountability and consequences, clear expectations and parameters, and active monitoring)?

Q2. Do correlations exist between the elements of a safe and supportive school climate and a teacher's (a) intrinsic motivation and (b) self-efficacy beliefs?

Q3. Is there a significant difference between (a) the intrinsic motivation and (b) self-efficacy of teachers who feel safe and supported in schools versus those that do not?

Q4. Which of the four elements of a safe and supportive school climate has the greatest impact on (a) intrinsic motivation and (b) self-efficacy of a teacher?

The data from the research questions incorporated a mixture of descriptive and inferential statistics that included the following: (a) Spearman's correlation (r) to measure the degree of association between variables (e.g., negative, positive or no correlation), (b) multiple regression analysis to determine the greatest impact, and (c) t-test analysis to determine statistically significant differences (Creswell, 2015). The correlational design was chosen for this study because groups were not controlled or randomly assigned (Creswell, 2015).

\subsection{Participants}

The target population of participants in this study were approximately 250 teachers from seven public schools in West Tennessee school districts. The participants ranged from middle school, junior high and high school teachers. No randomized sampling was included for the purpose of this study, but rather incorporated a population of convenience given the volunteer nature of the study among schools that were willing to participate in the study. The research group or convenience sample only comprised of 204 participating teachers with an overall response rate of $81 \%$ (i.e., 204 out of 250.

\subsection{Data Collection Tool}

The primary data collection tools for this study were the (a) the Safe and Supportive School Questionnaire and (b) the Attitude Toward Teaching Survey. The development of these instruments and items were based on both early and current theories. The theories consisted of behaviorism (Maslow, 1954), constructivism and self-efficacy (Bandura, 1997), instructional leadership (Green, 2013), social learning (Bandura, 2002), and organizational climate and culture (Epistein \& Buhavoc, 2014).

The Safe and Supportive School Questionnaire was created to obtain data regarding four elements of a safe and supportive school including, (a) positive staff relationships, (b) accountability and consequences, (c) clearly defined parameters and expectations, (d) and active monitoring. This questionnaire utilized eight questions that were vertically 
and horizontally aligned with the Safe and Supportive School initiatives (S3), which were designed by the researcher. The Safe and Supportive School initiatives were put in place by the Department of Education to improve conditions for learning and teaching, including school climate and safety, in today's schools. The Likert-scale instruments collected responses (strongly agree, agree, neither agree or disagree, disagree, strongly disagree) based on how participants personally perceive the elements of a safe and supportive school.

The Attitude Toward Teaching Survey created by Farmer (2010) utilized 17 questions. The original instrument was developed from literature surrounding major motivational concepts that have shown to have a positive impact on teacher effectiveness including (a) intrinsic motivation, (b) extrinsic motivation, (c) incremental beliefs, (d) collective efficacy, and (e) self-efficacy (Bandura, 1993; Blackwell et al., 2007; Elliot \& Dweck, 2005; Goodard et al., 2004; Meuller \& Dweck, 1998; Zimmerman, 2000). The current research did not utilize all items from the original survey as this research only explored intrinsic motivation and self-efficacy, thus only the items that measured intrinsic motivation and self-efficacy were used.

\subsection{Data Collection Procedures}

The researcher submitted the proposal to the university's Institutional Review Board (IRB) to conduct research. After approval of the submitted proposal, the researcher: (a) reviewed and submitted documentation to superintendents and principals for potential research requests, (b) made personal contact with principals when instructed that the principals were the final arbiter for the research request, (c) constructed a Google Form, and (d) submitted the Google link to the appropriate Tennessee schools with coded information collecting live data. Due to time constraints, job responsibilities of participants, comfort of confidentiality, and accuracy of data, the researcher utilized a password protected electronic survey to maintain participants" anonymity.

After receiving approval from the principals to participate in the study, the researcher submitted a Google Form to the principals, and the principals distributed the information through the schoolse emailing systems. An electronic consent form was emailed to provide the purpose of research, the clause of confidentiality, time completion of the survey, and contact information for questions or concerns. Participating teachers completed the survey from August 2016 through January 2016. Participants were aware that participation was voluntary, and review of responses was acceptable before complete submission.

\subsection{Limitations}

The scope of this study was limited in several areas. This study exclusively consisted of teachers, thus limiting the scope of perceptions from all stakeholders. Another limitation involves the sample population only consisting of teachers from rural West Tennessee school systems, representing teachers in the middle school grades through high school grades. The sample size is another limitation that should be taken into consideration. Although the sample population was very diverse, the findings in this study may have shown different trends if the sample size had been larger, included all stakeholders, and included all grade levels. Due to the limitations of this study, results from this study may not be appropriate for all demographical regions and educational settings.

\subsection{Content Validity and Reliability}

Creswell (2009) stated that the threat of statistical conclusion validity arises when the researcher's assumptions of the study are inaccurate due to inadequate statistical power or violation of statistical assumptions. Therefore, the Safe and Supportive School Questionnaire was tested for validity with a group of 376 high school students in Tennessee prior to the current study. The results revealed that this instrument could be used in other populations or situations and reflect similar outcomes. Ivie (2007) validated Green's (2006) Leadership Behavior Inventory through peer reviews of 156 educators (i.e., 20 principals and 136 teachers) regarding job satisfaction of teachers and principals implementing core competencies of leadership within various schools (Farmer, 2010).

Reliability was calculated for the Safe and Supportive School Questionnaire using means with Cronbach's alpha. The Cronbach alpha coefficient determined the Safe and Supportive School Questionnaire during the original study was significantly high. The questionnaire revealed an alpha of .739 during the initial study, which measured the degree to which students felt that their school exhibited elements of a safe and supportive school. Thus, indicating if used again, this questionnaire would provide consistent results in further research studies.

In the current research the Attitude Toward Teaching Survey, composed by Farmer, (2010) revealed moderately high reliability for self-efficacy $(\alpha=.67)$ and intrinsic motivation $(\alpha=.59)$. In the current study the researcher only used items that measured these two variables. The Safe and Supportive School Questionnaire revealed moderately high reliability for positive staff relationships $(\alpha=.611)$ and clear expectations and parameters $(\alpha=.724)$. Active monitoring and accountability and consequences revealed unacceptable reliability, thus only one question for each variable was used in the data analysis to answer the research questions. 


\section{Results}

\subsection{Participating Teachers' Demographic Data}

Table 1 shows the complete summary of 204 participating teacherse demographic statistical results that include race/ethnicity, and gender.

Table 1. Teacher Demographics

\begin{tabular}{lll}
\hline & Frequency & Percentage \\
\hline Ethnicity & & \\
African American & 55 & $27.0 \%$ \\
Caucasian & 135 & $66.2 \%$ \\
Hispanic & 0 & $0.0 \%$ \\
Asian & 1 & $0.5 \%$ \\
Other & 13 & $6.4 \%$ \\
Gender & & \\
Male & 69 & $33.8 \%$ \\
Female & 135 & $66.2 \%$ \\
\hline
\end{tabular}

Note. $n=204$ This is a demographical breakdown of the participants.

For the categorical variable, Race/Ethnicity, Caucasian $(\mathrm{n}=135)$ was the largest percentage of participants $(66.2 \%)$. The majority of the participants were female $(\mathrm{n}=135,66.2 \%)$, and males accounted for $33.8 \%$ (69). All participants were from public schools in West Tennessee school districts $(\mathrm{n}=204,100 \%)$.

\subsection{Results of Research Questions}

Q1. To what extent do teachers perceive that their schools exhibit specific elements of a safe and supportive school climate (i.e. positive staff relationships, accountability and consequences, clear expectations and parameters, and active monitoring)?

This research question explored the extent to which teachers perceived that their schools exhibited specific elements of a safe and supportive school climate (i.e. positive staff relationships, accountability and consequences, clear expectations and parameters, and active monitoring)? The observations for clear expectations and parameters, which included questions 16 and 19 from the Safe and Supportive School Questionnaire, ranged from 2.00 to 10.00, with an average of $8.77(S D=1.25)$. The observations for positive staff relationships, which included questions 12 and 14 , ranged from 2.00 to 10.00 , with an average of $8.39(S D=1.58)$. The observations for active monitoring, which included questions 7 and 26, ranged from 2.00 to 10.00 , with an average of $8.05(S D=1.41)$. The observations for accountability and consequence, which included questions 4 and 6, ranged from 2.00 to 9.00, with an average of $7.11(S D=1.58)$.

Overall, teachers perceived that their leadership had clear expectations and parameters in place $(M=8.77)$. In addition, teachers professed that staff members exhibit positive staff relationships at their school $(M=8.39)$. A mean of 8.05 , from responding teachers, believes that administrators and colleagues know and care about the extent to which job duties are performed. Finally, an average of 7.11, from responding teachers showed that teachers believed they were held accountable for their job performance and valued the administrators' opinion of their job performance.

Table 2. Summary Statistics Table for Numeric Variables Clear Expectations and Parameters, Positive Staff Relationships, Active Monitoring, and Accountability and Consequences

\begin{tabular}{lccccccc}
\hline Variable & $M$ & $S D$ & $n$ & Min. & Max. & Skewness & Kurtosis \\
\hline $\begin{array}{l}\text { Clear Expectations and Parameters } \\
\begin{array}{l}\text { Positive Staff } \\
\text { Relationships }\end{array}\end{array}$ & 8.77 & 1.25 & 204 & 2.00 & 10.00 & -1.68 & 5.84 \\
$\begin{array}{l}\text { Active Monitoring } \\
\text { Accountability and Consequences }\end{array}$ & 7.11 & 1.58 & 204 & 2.00 & 10.00 & -1.45 & 2.94 \\
& 8.05 & 1.41 & 204 & 2.00 & 10.00 & -0.90 & 1.30 \\
\hline
\end{tabular}

Q2. Do correlations exist between the elements of a safe and supportive school climate and a teacher's (a) intrinsic motivation and (b) self-efficacy beliefs?

This research question investigated whether or not correlations existed between the elements of a safe and supportive school climate and a teacher's intrinsic motivation. Spearman correlation analyses were conducted among the following variables: (a) accountability and consequences, (b) active monitoring, (c) clear expectation and parameters, and (d) 
positive staff relationships, and intrinsic motivation. Cohen's standard was used to evaluate the strength of the relationships, where coefficients between .10 and .29 represent a small association, coefficients between .30 and .50 represent a moderate association, and coefficients above .50 indicate a large association.

There was a significant negative correlation between accountability and consequences and intrinsic motivation $(\mathrm{r}=$ $-0.31, \mathrm{p}<.001)$. The correlation coefficient between accountability and consequences and intrinsic motivation was -0.31 , indicating a moderate, negative relationship. This indicated that as teachers felt as if they were held more accountable for their work, their intrinsic motivation decreased. There was a significant positive correlation between active monitoring and intrinsic motivation $(r=0.45, p<.001)$. The correlation coefficient between active monitoring and intrinsic motivation was 0.45 , indicating a moderate relationship. This indicated that as teachers felt more certain that administration, faculty, and staff members cared about their performance, the teachers' intrinsic motivation increased. There was a significant positive correlation between intrinsic motivation and clear expectations and parameters $(\mathrm{r}=0.57, \mathrm{p}<.001)$. The correlation coefficient between intrinsic motivation and clear expectations and parameters was 0.57 , indicating a large relationship. This indicated that as intrinsic motivation increased, teachers increased in their understanding of expectations, policies and procedures.

There was a significant positive correlation between intrinsic motivation and positive staff relationships $(\mathrm{r}=0.51, \mathrm{p}$ $<.001)$. The correlation coefficient between intrinsic motivation and positive staff relationships was 0.51 , indicating a large relationship. This indicated that as intrinsic motivation increased, the relationship among staff members became more positive. Table 3 presents the results of the correlations.

Table 3. Spearman Correlation Matrix among Accountability and Consequences, Active Monitoring, Clear Expectations and Parameters, Positive Staff Relationships, and Intrinsic Motivation

\begin{tabular}{lrrrrr}
\hline Variable & 1 & 2 & 3 & 4 \\
\hline 1. Accountability and Consequences & - & & & & \\
2. Active Monitoring & -0.35 & - & & & \\
3. Intrinsic Motivation & -0.31 & $* 0.45$ & - & & \\
4. Clear Expectations and Parameters & -0.35 & $* 0.48$ & $* 0.57$ & - & \\
5. Positive staff Relationships & -0.26 & $* 0.53$ & $* 0.51$ & $* 0.53$ & - \\
\hline
\end{tabular}

Note. The critical values are $0.14,0.18$, and 0.23 for significance levels $.05, .01$, and .001

Spearman correlation analyses were conducted among the following variables: accountability and consequences, active monitoring, clear expectation and parameters, positive staff relationships, and self-efficacy. Cohen's standard was used to evaluate the strength of the relationships, where coefficients between .10 and .29 represent a small association, coefficients between .30 and .50 represent a moderate association, and coefficients above .50 indicate a large association.

There was a significant negative correlation between accountability and consequences and self-efficacy $(r=-0.21, p$ $=.002$ ). The correlation coefficient between accountability and consequences and self-efficacy was -0.21 , indicating a small relationship. This indicated that as accountability and consequences increased, self-efficacy decreased. There was a significant positive correlation between active monitoring and self-efficacy $(r=0.50, p<.001)$. The correlation coefficient between active monitoring and self-efficacy was 0.50 , indicating a moderate relationship. This indicated that the more a teacher felt that the administration, faculty, and staff members cared about his or her job performance, the teacher's self-efficacy increased.

There was a significant positive correlation between clear expectation and parameters and self-efficacy $(r=0.46, p$ $<.001)$. The correlation coefficient between clear expectation and parameters and self-efficacy was 0.46 , indicating a moderate relationship. This indicated that as clear expectation and parameters increased, a teacher's self-efficacy also increased. There was a significant positive correlation between positive staff relationships and self-efficacy $(r=0.44, p$ $<.001)$. The correlation coefficient between positive staff relationships and self-efficacy was 0.44 , indicating a moderate relationship. This indicated that as staff relationships became more positive, a teacher's self-efficacy increased. Table 4 presents the results of the correlations. 
Table 4. Spearman Correlation Matrix among Accountability and Consequences, Active Monitoring, Clear Expectations and Parameters, Positive Staff Relationships, and Self-Efficacy

\begin{tabular}{llllll}
\hline Variable & 1 & 2 & 3 & 4 & 5 \\
\hline 1. Accountability and Consequences & - & & & & \\
2. Active Monitoring & -0.35 & - & & & \\
3. Clear Expectations and Parameters & -0.35 & $* 0.48$ & - & & \\
4. Positive Staff Relationships & -0.26 & $* 0.53$ & $* 0.53$ & - & \\
5. Self-Efficacy & -0.21 & $* 0.50$ & $* 0.46$ & $* 0.44$ & - \\
\hline
\end{tabular}

Note. The critical values are $0.14,0.18$, and 0.23 for significance levels $.05, .01$, and .001

Q3. Is there a significant difference between (a) the intrinsic motivation and (b) self-efficacy of teachers who feel safe and supported in schools versus those that do not?

An independent samples $t$-test was conducted to examine whether the mean of intrinsic motivation was significantly different between teachers who felt safe and supported in schools versus those that did not. Teachers were placed in two groups (low or high) based on their responses to questions 4, 7, 12, 14, 16, 19, and 26. Teachers were placed in the low group if their score ranged between 0-24. Teachers were placed in the high group if their score ranged between 25-35.

The result of the independent samples $t$-test was significant, $t(202)=-5.91, p<.001$, suggesting that the mean of intrinsic motivation was significantly different between the low group and high group. The intrinsic motivation in the low group was significantly lower than the intrinsic motivation in the high group. Data revealed that those who felt safe and supported within their school had significantly higher intrinsic motivation. Table 5 presents the results of the independent samples $t$-test.

Table 5. Independent Samples t-Test for the Difference Between Intrinsic Motivation

\begin{tabular}{lllllllll}
\hline & \multicolumn{3}{l}{ Low group } & \multicolumn{2}{l}{ High group } & & & \\
Variable & $M$ & $S D$ & $M$ & $S D$ & $t$ & $p$ & $d$ \\
\cline { 2 - 6 } & & $M$ & & & & \\
\hline
\end{tabular}

$\begin{array}{llllllll}\text { Intrinsic motivation } & 18.79 & 3.81 & 21.75 & 2.18 & -5.91 & <.001 & 0.95\end{array}$

Note. Degrees of Freedom for the $t$-statistic $=202 . d$ represents Cohen's $d$.

An independent samples t-test was conducted to examine whether the mean of self-efficacy was significantly different between teachers who feel safe and supported in schools versus those that did not. Teachers were placed in the low group if their responses to questions $4,7,12,14,16,19$, and 26 ranged from $0-24$. Teachers were placed in the high group if their responses ranged from 25-35.

The result of the independent samples t-test was significant, $t(202)=-7.23, p<.001$, suggesting that the mean of self-efficacy was significantly different between the low group and high group. The mean of self-efficacy in the low group was significantly lower than the mean of self-efficacy in the high group. Data revealed that those who felt safe and supported within their school had significantly higher self-efficacy. Table 6 presents the results of the independent samples $\mathrm{t}$-test.

Table 6. Independent Samples t-Test for the Difference between self-efficacy

\begin{tabular}{llllllll}
\hline & Low group & \multicolumn{2}{l}{ High group } & & & \\
\cline { 2 - 7 } Variable & $M$ & $S D$ & $M$ & $S D$ & $t$ & $p$ & $d$ \\
\hline Self-efficacy & 19.07 & 3.10 & 22.07 & 1.82 & -7.23 & $<.001$ & 1.18 \\
\hline
\end{tabular}

Note. Degrees of Freedom for the $t$-statistic $=202 . d$ represents Cohen's $d$.

Q4. Which of the four elements of a safe and supportive school climate has the greatest impact on (a) intrinsic motivation and (b) self-efficacy of a teacher?

This question investigated which of the four elements of a safe and supportive school climate has the greatest impact on intrinsic motivation. A multiple linear regression analysis was conducted to assess whether a significant relationship existed between accountability and consequence, active monitoring, clear expectation and parameters, positive staff relationships and intrinsic motivation. Variance Inflation Factors (VIFs) were calculated to detect the presence of multicollinearity between predictors. High VIFs indicate increased effects of multicollinearity in the model. Variance 
Inflation Factors greater than 6 are cause for concern, whereas a VIF of 10 should be considered the maximum upper limit. All predictors in the regression model have variance inflation factors less than 10. Table 7 presents the VIF for each predictor in the model.

Table 7. Variance Inflation Factors for Accountability and Consequences, Active Monitoring, Clear Expectations and Parameters, and Positive Staff Relationships.

\begin{tabular}{ll}
\hline Variable & $V I F$ \\
\hline Accountability and Consequences & 1.11 \\
Active Monitoring & 1.37 \\
Clear Expectations and Parameters & 1.54 \\
Positive Staff Relationships & 1.49
\end{tabular}

The results of the linear regression model were significant, $F(4,199)=47.92, p<.001, R^{2}=0.49$, indicating that approximately $49 \%$ of the variance in intrinsic motivation was explainable by teachers' perceptions of accountability and consequences, active monitoring, clear expectations and parameters, and positive staff relationships. Active monitoring was not a significant predictor of intrinsic motivation, $B=-0.08, t(199)=-0.84, p=0.403$. Based on this sample, a one-unit increase of accountability and consequences did not have a significant effect on intrinsic motivation. Accountability and consequences significantly predicted intrinsic motivation, $B=0.46, t(199)=2.23, p=0.027$. This indicated that on average, every one-unit increase of active monitoring resulted in a 0.46 unit change in intrinsic motivation. Clear expectations and parameters significantly predicted intrinsic motivation, $B=0.89, t(199)=6.65, p$ $<.001$. This indicated that on average, every one-unit increase of clear expectations and parameters resulted in a 0.89 unit change in intrinsic motivation. Positive staff relationships significantly predicted intrinsic motivation, $B=0.47$, $t(199)=4.48, p<.001$. This indicated that on average, every one-unit increase of positive staff relationships resulted in a 0.47 unit change in intrinsic motivation. Table 8 summarizes the results of the regression model.

Table 8. Results for Multiple Linear Regression with Accountability and Consequences, Active Monitoring, Clear Expectations and Parameters, and Positive Staff Relationships predicting Intrinsic Motivation

\begin{tabular}{|c|c|c|c|c|c|}
\hline Variable & $B$ & $S E$ & $\beta$ & $t$ & $p$ \\
\hline Intercept & 7.90 & 1.20 & 0.00 & 6.56 & $<.001$ \\
\hline Accountability and Consequences & -0.08 & 0.10 & -0.04 & -0.84 & .403 \\
\hline Active Monitoring & 0.46 & 0.21 & 0.13 & 2.23 & .027 \\
\hline Clear Expectations and Parameters & 0.89 & 0.13 & 0.42 & 6.65 & $<.001$ \\
\hline Positive Staff Relationships & 0.47 & 0.10 & 0.28 & 4.48 & $<.001$ \\
\hline
\end{tabular}

Note. $F(4,199)=47.92, p<.001, R^{2}=0.49$

Table 9. Variance Inflation Factors for Accountability and Consequence, Active Monitoring, Clear Expectations and Parameters, and Positive Staff Relationships

\begin{tabular}{ll}
\hline Variable & $V I F$ \\
\hline Accountability and Consequence & 1.11 \\
Active Monitoring & 1.37 \\
Clear Expectations and Parameters & 1.54 \\
Positive Staff Relationships & 1.49
\end{tabular}

Results of the linear regression model were significant, $F(4,199)=27.51, p<.001, R^{2}=0.36$, indicating that approximately $36 \%$ of the variance in self-efficacy is explainable by accountability and consequence, active monitoring, clear expectations and parameters, and positive staff relationships, and self-efficacy. Accountability and consequence was not a significant predictor of a teacher's self-efficacy, $B=-0.04, t(199)=-0.33, p=0.743$. Based on this sample, a one-unit increase of accountability and consequence did not have a significant effect on self-efficacy. Active monitoring significantly predicted a teacher's self-efficacy, $B=0.91, t(199)=3.85, p<.001$. This indicated that on average, every one-unit increase of active monitoring resulted in a 0.91 unit change in a teacher's self-efficacy. Clear expectations and parameters significantly predicted self-efficacy, $B=0.55, t(199)=3.61, p<.001$. This indicated that on average, every one-unit increase of clear expectations and parameters resulted in a 0.55 unit change in self-efficacy. Positive staff relationships significantly predicted self-efficacy, $B=0.38, t(199)=3.22, p=0.002$. This indicated that on average, every one-unit increase of positive staff relationships resulted in a 0.38 unit change in self-efficacy. Table 10 summarizes the results of the regression model. 
Table 10. Results for Multiple Linear Regression with Accountability and Consequence, Active Monitoring, Clear Expectations and Parameters, and Positive Staff Relationships predicting Self-Efficacy

\begin{tabular}{lllllll}
\hline & Variable & $B$ & $S E$ & $\beta$ & $t$ & $p$ \\
\hline & (Intercept) & 13.87 & 1.38 & 0.00 & 10.06 & $<.001$ \\
& Accountability and Consequence & -0.04 & 0.11 & -0.02 & -0.33 & .743 \\
& Active Monitoring & 0.91 & 0.24 & 0.26 & 3.85 & $<.001$ \\
& Clear Expectations and & & & & & \\
& Parameters & 0.55 & 0.15 & 0.25 & 3.61 & $<.001$ \\
& Positive Staff Relationships & 0.38 & 0.12 & 0.22 & 3.22 & .002 \\
\hline
\end{tabular}

Note. $F(4,199)=27.51, p<.001, R^{2}=0.36$

\section{Discussion and Conclusion}

A search of previous literature reveals that positive school climate is associated with stronger academic performance, higher graduation rates, decreased incidences of violence and increased teacher retention (Clifford, Menon, Condon, \& Hornung, 2012; Gangi, 2010; Haggerty, Elgin \& Woodley, 2010). Previous research also proposed that a positive school climate makes school an appealing, satisfying, and meaningful situation in which both adults and youth spend a substantial portion of their time (Connolly, Pryseski, \& Smith, 2014). The focus of this study was to identify elements that teachers perceived as significant to their connection with school climate, intrinsic motivation, and self-efficacy beliefs at the workplace. According to Clark and Reaves, it is paramount that educational leaders and policymakers stay abreast of evolving changes within the teaching profession by continually researching, monitoring, and improving programs to ensure success for all stakeholders.

The results from the current study added to the growing body of literature about perceptions, motivation, and self-efficacy. These findings help close the gap in literature because understanding these areas are critical to the sustainability of a healthy school system as an organization, as well as retention of teachers as pillars upon which teaching and learning is built. Data revealed that there is a connection among a teacher's perceptions of elements of a safe and supportive school climate to motivation, and self-efficacy. Another conclusion that evolved from this study is teachers who feel safe and supported had significantly higher intrinsic motivation and self-efficacy compared to teachers that did not feel safe and supported. Specifically, possessing clear expectations and parameters from their administration had the greatest impact on a teacher's intrinsic motivation, while having administrators actively monitor their teaching behavior had the greatest impact on self-efficacy.

\section{References}

Adeogun, A. A., \& Olisaemeka, B. U. (2011). Influence of School Climate on Students' Achievement and Teachers' Productivity For Sustainable Development. US-China Education Review, 8(4), 552-557.

Aldridge, J., \& Ala'l, K. (2013). Assessing Students' Views of School Climate. Improving Schools, 16(45), 47-66. https://doi.org/10.1177/1365480212473680

Allen, N., Brian, G., \& Peters, M. L. (2015). Does leadership matter? Examining the relationship among transformational leaders, school climate, and achievement. International Journal of Educational Leadership Preparation, 10(2), 1-22.

Aloe, A. M., Amo, L. C., \& Shanahan, E. (2014). Classroom Management Self-Efficacy and Burnout: A Multivariate Meta-Analysis. Educational Psychology Review, 26(1), 101-126. https://doi.org/10.1007/s10648-013-9244-0

Anderson, C. (1982). The Search For School Climate: A Review Of The Research. Review of Educational Research, 52(3), 368-420. https://doi.org/10.3102/00346543052003368

Anhorn, R. (2008). The Profession That Eats Its Young. The Delta Kappa Gamma Bulletin, 73(3), 15-21.

Ashley, D. M. (2015). It's about relationships: Creating positive school climates. American Educator, 39(4), 13-18.

Associated Press. (1997, December 2). Student fires on prayer group at school; 2 dead, 6 wounded. Charleston Gazette, p. P7A. Retrieved November 28, 2015, from LexisNexis database

Association for Supervision and Curriculum Development (2002). School organization. Alexandria, VA: ASCD.

Averch, H. A., Carroll, S. J., Donaldson, T. S., Kiesling, H. J., \& Pincus, J. (1974). How effective is schooling? A critical review of research. Englewood Cliffs, NJ: Educational Technology Publications. 
Bailey, M. (1979). The art of positive principalship. Momentum, 10(1), 46-47. Retrieved from ERIC Document Reproduction Services. (No. EJ218917)

Bandura, A. (1977). Social learning theory. Alexandria, VA: Prentice Hall.

Bandura, A. (1997). Self-efficacy. The exercise of control. New York, NY: Harper \& Rowe.

Bandura, A. (2002). Social cognitive theory: An agentic perspective. Annual Review of Psychology, 52, 1-26. https://doi.org/10.1146/annurev.psych.52.1.1

Bao, Z., Li, D., Zhang, W., \& Wang, Y. (2015). School climate and delinquency among Chinese adolescents: Analysis of effortful control as a moderator and deviant peer as mediator. Journal of Abnormal Child Psychology, 43(1), 81-93. https://doi.org/10.1007/s10802-014-9903-8

Barnett, J., \& Hudgens, T. M. (2014). Staying power: The impact of the TAP system on retaining teachers nationwide: National Institute for Excellence in Teaching. Retrieved from ERIC Document Reproduction Services. (No. ED556342)

Bishop, J., Cardichon, J., \& Roc, M. (2014). Climate change: Improving school climate by supporting great teaching. Washington D.C.: Alliance For Excellent Education. Retrieved from https://www.shastacoe.org/uploaded/Dept/is/LCAP-local_control_accountability_plans/aae-climatechange(1).pdf

Blaszak, B. (2010). Preventing "Back-atcha": Improving secondary school instruction by introducing prospective teachers to historiography. History Teacher, 43(3), 435-439.

Boe, E. E., Cook, L. H., \& Sunderland, R. J. (2008). Teacher turnover: Examining exit attrition, teaching area transfer, and school migration. Council for Exceptional Children, 75(1), 7-31. https://doi.org/10.1177/001440290807500101

Boulifa, K., \& Kaaouachi, A. (2015). The relationship between students' perception of being safe in school, principals' perception of school climate and science and achievement in TIMSS 2007: A comparison. International Education Studies, 8(1), 100-112.

Bronfenbrenner, U. (1979). The ecology of human development: Experiments by nature and design. Cambridge, MA: Harvard University Press.

Brookover, W. B., \& Erickson, E. L. (1975). Sociology of education. Homewood, Ill.: Dorsey Press.

Brookover, W. B., Beady, C., Flood, P., Schweitzer, J., \& Wisenbaker, J. (1979). School social systems and student achievement: Schools can make a difference. New York: Praeger.

Brunstig, N. C., Sreckovic, A., \& Lane, K. L. (2014). Special education teacher burnout: A synthesis of research from 1979-2013. Education \& Treatment of Children, 37(4), 681-711. https://doi.org/10.1353/etc.2014.0032

Buchanan, J., Prescott, A., Schuk, S., Aubusson, P., \& Burke, P. (2013). Teacher retention and attrition: Views of early career teacher. Australian Journal of Teacher Education, 38(3), 1-20. https://doi.org/10.14221/ajte.2013v38n3.9

Bushardt, S. C., Lambert, J., \& Duhon, D. L. (2007). Selecting a better carrot: Organizational learning, formal rewards and culture - a behavioral perspective. Journal of Organizational Culture, Communication and Conflict, 11(2), 67-79.

Cabansag, M. G. (2013, October ). Career motivational beliefs and teachers'. Researchers World, 4(4), 12. Retrieved Janurary 27, 2017, https://doi.org/10.1093/cs/28.4.219

Cameron, M. (2006). Managing school discipline and implication for school social workers: A review of the literature. Children \& Schools, 28(4), 219-227.

Catlett, R. D. (2015). The relationship between affective teaching and teacher effectiveness in rural teachers in Tennessee. The University of Memphis. Retrieved from ProQuest Dissertations Publishing. (No. 3728350)

Cheng, L. (2014). Attitudes of principals toward approach used to deal with teacher competence. Social Behavior and Personality, 42(1), 155-176. https://doi.org/10.2224/sbp.2014.42.1.155

Christensen, R., \& Knezek, G. (2015). The climate change attitude survey: measuring middle school student beliefs and intentions to enact positive environmental change. International Journal of Environmental and Science Education, 10(5), 773-788.

Clark, C. H., \& Reaves, S. J. (2014). Together everyone achieves more: 33 1/3 The complete educational process. Portland, Oregon: Bookbaby.com.

Clement, M. C. (2000). Building the best faculty: Strategies for hiring and supporting new teachers. Lanham, MD: 
Scarecrow Press.

Cohen, J., McCabe, E., Michelli, N., \& Pickeral, T. (2009). School climate: Research, policy, practice, and teacher education. Retrieved from http://www.scrc.schoolclimate.org/pdf/school-Climate-Paper-TC-Record.pdf

Corkett, J., Hatt, B., \& Benevides, T. (2011). Student and teacher self-efficacy and the connection to reading and writing. Canadian Journal of Education, 34(1), 65-98.

Cram 101. (2017). Just the facts 101: Psychology applied to modern life, adjustment in the 21st Century (11th ed.). Lewisville: Content Technologies, Inc. Retrieved February 14, 2017, from https://books.google.com/books?id=TYnSCwAAQBAJ\&pg=PT67\&lpg=PT67\&dq=Portions+of+an+individual\%2 $7 \mathrm{~s}+$ knowledge+acquisition+can+be+directly+related+to+observing+others+within+the+context+of+social+interac tions,+experiences, +and+outside+media+influences.\&source

Creemers, B., \& Reeigt, G. (1999). The role of school and classroom climate in elementary school learning environments. In H. J. Freiberg (Ed.), School climate: Measuring, improving and sustaining healthy learning environments. Philadelphia, PA: Falmer Press.

Creswell, J. W. (2009). Research design: Qualitative, quantitative, and mixed approaches ( $3^{\text {rd }}$ ed.). Thousand Oaks, CA: Sage Publications.

Cunningham, W. G., \& Cordeiro, P. A. (Eds.). (2006). Educational leadership. A problem-based approach (3 ${ }^{\text {rd }}$ ed.). Boston, MA: Pearson.

Curry, A. G. (1993). Teachers' perceptions of factors contributing to their self-efficacy and satisfaction with teaching. A naturalistic study. Southern Illinois University at Carbondale. Retrieved from ProQuest Dissertation Publishing. (No. 9403062)

Dagli, U. Y. (2012). America's public school kindergarten teachers' job turnover and associated factors. Kuram ve Uygulamada Egitim Bilimier, suppl. Special Issue, 12(4), 3121-3134.

Daniels, A. (2014). Semper fidelis. A recipe for leading others. Supervision, 75(9), 6-8.

Darling-Hammond, L. (1997). Doing what matters most: Investing in quality teaching. New York: National Commission on Teaching and America's Future.

Darling-Hammond, L. (2003). Keeping good teachers: Why it matters, what leaders can do. Educational Leadership, 60(8), 6-13.

Darling-Hammond, L. (2007). Recruiting and Retaining Teachers: What Matters Most and What Can Government Do?.

Darling-Hammond, L., \& Sykes, G. (2003). Wanted: A national manpower policy for education. Denver, CO: The Educational Commission of the States.

David, J. (2008). Teacher recruitment incentives. Educational Leadership, 65(7), 84-86.

Dorer, H., \& Mahoney, J. M. (2006). Self-actualization in the corporate hierarchy. North American Journal of Psychology, 8(2), 397-409.

Dreeben, R. (1968). On what is learned in school. Reading, MA: Addison-Wesley.

Driscoll, M. P. (Ed.). (2005). Psychology of learning for instruction. ( ${ }^{\text {rd }}$ ed.). Boston, MA: Pearson.

Dumay, X. (2009). Origins and consequences of schools' organizational culture student achievement. Educational Administration Quarterly, 45(4), 523-555. https://doi.org/10.1177/0013161X09335873

Dunn, A. H. (2015). The courage to leave: Wrestling with decision to leave teaching in uncertain times. Urban Review, 47(1), 84-103. https://doi.org/10.1007/s11256-014-0281-X

Durkheim, E. (1982). Preface to second edition. Rules of sociological methods and selected texts on sociology and its method (pp. 34-47). Steven Luke (Ed.), translated by W. D. Halls. New York, NY: The Free Press.

Eginli, I. (2009). Principal leadership and teacher commitment to the profession. The mediating role of collective efficacy and teacher efficacy. George Mason University. Retrieved from ProQuest Dissertations Publishing. (No. 3367063)

Egwu, S. O. (2015). Principals' performance in promoting learning climate in Ebonyi state secondary schools. Journal of Education and Practice, 6(19), 4-70.

Ellerbrock, C. R., \& Kiefer, S. M. (2010). Reacting a ninth-grade community of care. Journal of Educational Research, 103(6), 393-406. https://doi.org/10.1080/00220670903383085 
Ferrans, S. D., \& Selman, R. L. (2014). How students' perceptions of school climate influence their choice to upstand, to bystand or to join perpetrators of bullying. Harvard Educational Review, 84(2), 12-187. https://doi.org/10.17763/haer.84.2.h4883134101651mm

Fisher, J. G., Maines, L. A., Peffer, S. A., \&Sprinkle, G. B. (2005). An experimental investigation of employer discretion in employee performance evaluation and compensation. The Accounting Review, 80(2), 563-583. https://doi.org/10.2308/accr.2005.80.2.563

Foster, H., \& Brooks-Gums, J. (2013). Neighborhood, family and individual influences on school victimization. Journal of Youth Adolescence, 42(10), 1596. https://doi.org/10.1007/s10964-012-9890-4

Fraser, A. J. (2004). A return to basics at Kellogg. MIT Sloan Management Review, 45(4), 27-33.

Futernick, K. (2007). A possible dream: Retaining California teachers so all students learn. Sacramento: California State University-Sacramento. Retrieved July 5, 2015 from https://www.calstate.edu/teacherquality/documents/possible_dream.pdf

Garvis, S. (2013). Beginning generalist teacher self-efficacy for music and compared with maths and English. British Journal of Music Education, 30(1), 85-101. https://doi.org/10.1017/S0265051712000411

Good, T. L., \& Brophy, J. E. (2008). Looking into classrooms. Boston, MA: Pearson.

Grace, R. A., \& Harrington, S. Y. (2015). Our children and our schools: seeking solutions for improving the climate in urban public schools. Alabama Journal of Educational Leadership, 2, 1-14.

Gray, D. L., Anderson, E. M., \& O’Connell, A. A. (2011). Association of teacher credibility and teacher affinity with learning outcomes in health classroom. Social Psychology of Education Journal, 14(2), 185-205. https://doi.org/10.1007/s11218-010-9143-x

Green, R. L. (2013). Practicing the art of leadership: A problem-based approach to implementing the ISLLC standards $\left(4^{\text {th }}\right.$ ed.). New York, NY: Pearson, Inc.

Greenlee, B., \& Brown, Jr. J. (2009). Retaining teachers in challenging schools. Education, 130(1), 96-109.

Grigsby, J. (2008). Positive reinforcement: The value of zapping. Receivables Report for America's HealthCare Financial Managers, 23(11), 8-10.

Grossman, R. P. \& Till, B. D. (1998). The persistence of classical conditioned brand attitudes. Journal of Advertising, 27(1), 23-31. https://doi.org/10.1080/00913367.1998.10673540

Gruenert, S. (2008). School culture, they are not the same. Principal, 87(4), 56-59.

Gulsen, C., \& Gulenay, G. B. (2014). The principal and healthy school climate. Social Behavior and Personality Supplement, 1(42), 93-100. https://doi.org/10.2224/sbp.2014.42.0.S93

Hall, G., \& Hord, S. (2006). Implementing change: Patterns, principles, and potholes ( $3^{\text {rd }}$ ed.). Boston, MA: Pearson Education Inc.

Hands, C. M. (2014). Youth perspectives on community collaboration in education: Are students innovative developers, active participants, or passive observers of collaborative activities? School Community Journal, 24(1), 69-97.

Hargreaves, A. (1995). School effectiveness and school improvement. An International Journal of Research, Policy and Practice, 6(1), 22-46.

Hertberg-Davis, H., \& Brighton, C. (2006). Support and sabotage: Principals' Influence on Middle school teachers' responses to Differentiation. Journal of Secondary Gifted Education, 8, 90-102. https://doi.org/10.4219/jsge-2006-685

High School Dropouts in America. (2010). Alliance for Excellent Education, 1-3. Retrieved July5, 2015, from http://all4ed.org/reports-factsheets/high-school-dropouts-in-america-updated/

Hirsch, E. (2004). Teacher working conditions are student learning conditions: A report to Governor Mike Easley on the 2004 North Carolina teacher working conditions survey. Chapel Hill, NC: Southeast Center for Teacher Quality. Retrieved September 20, 2007, from http://www.teachingquality.org

Hoy, W. K., \& Hannum, J. W. (1997). Middle school climate: An empirical assessment of organizational health and student achievement. Educational Administration Quarterly, 33(3), 290-311. https://doi.org/10.1177/0013161X97033003003

Hoy, W. K., \& Tarter, C. J. (1997). The Road to Open and Healthy Schools: A Handbook for Change, Elementary and Middle School Edition (Thousand Oaks, CA: Corwin). 
Hoy, W., \& Miskel, C. (2008). Educational administration: Theory, research and practice ( $8^{\text {th }}$ ed.). Boston, MA: McGraw-Hill

Hughes, A. L., Matt, J. J., \& O'Reilly, F. L. (2015). Principal support is imperative to the retention of teachers in hard-to-staff schools. Journal of Education Training Studies, 3(1), 129-134.

Hughes, R. L., Beatty, K. C., \& Dinwoodie, (2014). Becoming a strategic leader: Your role in your organization's enduring success. San Francisco, CA: Jossey-Bass.

Hunt, J., \& Carroll, T. (2002). Unraveling the "teacher shortage" problem: Teacher retention is the key. Washington, DC: National Commission on Teaching and America's Future. Retrieved June 10, 2006 from http://www.ncsu.edu/mentorjunction/text_files/teacher_retentionsymposium.pdf

Ice, M., Thapa, A., \& Cohen, J. (2015). Recognizing community voice and a youth-led school-community partnership in the school climate improvement process. School Community Journal, 25(1), 9-28.

Ingersoll, R. M. (2001). Teacher turnover and teacher shortages: An organizational analysis. American Educational Research Journal, 38(3), 499-534. https://doi.org/10.3102/00028312038003499

Ingersoll, R. M. (2003b). Who controls teachers' work? Power and accountability in America's schools. Cambridge, MA: Harvard University Press.

Ingersoll, R. M., \& Smith, T. M. (2003). The wrong solution to the teacher shortage. Educational Leadership, 60(8), 30-33, 91.

Ingersoll, R. M., \& Smith, T. M. (2004). Does teacher induction and mentoring matter? NASSP Bulletin, 88(638), 28-40. https://doi.org/10.1177/019263650408863803

Inman, D., \& Marlow, S. (2004). Teacher retention: Why do beginning teachers remain in the profession? Education, 124(4), 605-614.

Johnson, S. (2006). The workplace matters: Teacher quality, retention, and effectiveness. Washington, DC: National Education Association.

Johnson, S. M., \& Birkeland, S. E. (2003). Pursuing a "sense of success": New teachers explain their career decisions. American Educational Research Journal, 40(3), 581-617. https://doi.org/10.3102/00028312040003581

Jones, V., \& Jones, L. (2013). Comprehensive classroom management. Creating communities of support and solving problems. Boston, MA: Pearson

Kalkan, F. (2016). Relationship between professional learning community, bureaucratic structure and organizational trust in primary education schools. Kuram ve Uygulamada Egitim Bilimleri, 16(5), 1619-1637.

Karadag, E., Baloglu, N., \& Cakir, A. (2011). A path analysis study of school culture and teachers' organizational commitment. Policy Futures in Education, 9(5), 573-384. https://doi.org/10.2304/pfie.2011.9.5.573

Keesler, V., \& Schneider, B. (2010). Estimating cause: Teacher turnover and school effectiveness in Michigan. Retrieved from ERIC Document Reproduction Services. (No. ED513944)

Kim, H. Y., Schwartz, K., \& Capella, E. (2014). Navigating middle grades: Role of social contexts in middle grade school climate. American Journal of Community Psychology, 54(1-2), 28-45. https://doi.org/10.1007/s10464-014-9659-x

Kinner, A. T., Barbinski, L. M., \& Clifford, E. J. (2013). Teachers' expectations and self-efficacy for working with bullies and victims. Psychology in the Schools, 51(1), 72-84. https://doi.org/10.1002/pits.21735

Klassen, R. M. (2010). Teacher stress: The mediating role of collective efficacy beliefs. Journal of Educational Research, 103(5), 342-380. https://doi.org/10.1080/00220670903383069

Klein, S. M. (1973). Pay factors as predictors to satisfaction. A comparison of reinforcement, equity, and expectancy. Academy of Management Journal, 16(4), 598-610.

Koltko-Rivera, M. E. (2006). Rediscovering the later version of Maslow's hierarchy of needs: Self transcendence and opportunities for theory, research, and unification. Review of General Psychology, 10(4), 302-317. https://doi.org/10.1037/1089-2680.10.4.302

Konkle, C. (2007). An examination of leadership styles of school principals and students effectiveness in urban elementary schools in the state of Ohio. Doctoral Dissertation, 2007. Retrieved from ProQuest Information and Learning Company. (No. 3113852)

Kottler, J. (1997). What's really said in the teachers' lounge: Provocative ideas about cultures and classrooms. Thousand 
Oaks, California: Corwin Press.

Kritek, W. J. (1986). School Culture and School Improvement. Paper presented at the Annual Meeting of the American Educational Research Association, San Francisco, CA, April 16-20.

Kumar, A. G. (2010). A study on group differences in the relationship between organizational climate perception and teaching competence of primary school teachers. Retrieved from ERIC Document Reproduction Services. (No. ED510279)

LaRusso, M., \& Selman, R. (2011). Early adolescent health risk health, conflict resolution strategies, and school climate. Journal of Applied Developmental Psychology, 32(6), 354-362.

https://doi.org/10.1016/j.appdev.2011.05.003

Leithwood, K., Harris, A., \& Strauss, T. (2010). Leading school turnaround: How successful leaders transform low-performing schools. San Francisco, CA: Jossey-Bass.

Lester, L., \& Cross, D. (2015). Relationship between school climate and emotional well-being over the transition from primary to secondary school. Psychology of Well-Being, 5(1), 1-15. https://doi.org/10.1186/s13612-015-0037-8

Liu, E. (2005). Hiring, job satisfaction, and the fit between new teachers and their schools. Paper presented at the annual meeting of the American Educational Research Association, Montreal, Canada.

Lochmiller, C. R., Sugimoto, T. J., \& Muller, P. A. (2016). Teacher retention, mobility, and attrition in Kentucky public schools from 2008-2012. REL 2016-116. Retrieved from ERIC Document Reproduction Services. (No. ED562734)

Loeb, S., Darling-Hammond, L., \& Luczak, J. (2005). How teaching conditions predict teacher turnover in California schools. Peabody Journal of Education, 80(3), 44-70. https://doi.org/10.1207/s15327930pje8003_4

Lorente, L., Salanova, M., Martinez, I. M., \& Vera, M. (2014). How personal resources predict work engagement and self-rated performance among construction workers: A social cognitive perspective. International Journal of Psychology, 49(3), 2000-2007. https://doi.org/10.1002/ijop.12049

Loukas, A. (2007). What is school climate? NAESP, 5(1), 1-3.

Luekens, M. T., Lyter, D. M., Fox, E. E., \& Chandler, K. (2004). Teacher attrition and mobility: Results from the teacher follow-up survey, 2000-01. NCES 2004-301, US Department of Education, National Center for Educational Statistics. Washington, DC: US Government Printing Office.

Lunenburg, F. C. (2010). Schools as open systems. Schooling, 1(1), 1-5.

Lynch, A. D., Lerner, R., \& Leventhal, T. (2013). Adolescent academic achievement and school engagement: an examination of the role of school-wide peer culture. Journal of Youth and Adolescence, 42(1), 6-19. https://doi.org/10.1007/s10964-012-9833-0

Martin, A. J., \& Dowson, M. (2009). Interpersonal relationships, motivation, engagement, and achievement: Yields for theory, current issues and educational practice. Review of Educational Research, 79(1), 327-365. https://doi.org/10.3102/0034654308325583

Marzano, R. J., Marzano, J. S., \& Pickering, D. J. (2003). Classroom management that works. Research-based strategies for every teacher. Alexandria, VA: Association for Supervision and Curriculum Development.

Maslow, A. (1954). Motivation and personality. New York, NY: Harper.

Maslow, A. H. (1968). Toward a Psychology of Being. New York: D. Van Nostrand Company.

McCollum, E. C., \& Yader, N. P. (2011). School culture, teacher regard and academic aspirations among middle school students. Middle Grades Research Journal, 6(2), 65-74.

Mehta, J. (2013). From bureaucracy to profession: remaking the educational sector for the twenty-first century. Harvard Educational Review, 83(3), 463-488. https://doi.org/10.17763/haer.83.3.kr08797621362v05

Meng, F., Zhang, J., \& Huang, Z. (2014). Perceived organizational health as a mediator for job expectations: A multidimensional integrated model. Public Personnel Management, 43(3), 355-370. https://doi.org/10.1177/0091026014535181

Merrit, E. G., Wanless, S. B., Rimm-Kaufman, S. E., Cameron, C., \& Peugh, J. L. (2012). The contribution of teachers' emotional support to children's social behaviors and self-regulatory skills in first grade. School Psychology Review, 41(2), 141-159.

Mitchell, J., \& Willower, D. (1992). Organizational culture in a well performing high school. Journal of Educational 
Administration, 30(1), 6-16. https://doi.org/10.1108/09578239210008781

Moos, R. (1974). Systems for the assessment and classification of human environments: An overview. In R. Moos, \& P. Insel, (Eds.), Issues in social ecology (pp. 5-28). Palo Alto, CA: National Press Books.

Mortimore, P., Sammons, P., Stoll, L., Lewis, D., \& Ecob, R. (1988). School matters: The junior years. Wells: Open Books.

National Commission on Teaching and America's Future [NCTAF]. (2003). No Dream Denied: A Pledge to America's Children. Washington, DC: Author. Retrieved on December 6, 2015, from https://nctaf.org/wp-content/uploads/2012/01/no-dream-denied_summary_report.pdf

National Education Association. (2003). Status of the American public school teacher. Retrieved on December 6, 2015, from http:// http://www.silccenter.org/aigaion2/index.php/publications/show/1469

National School Climate Center. (2007). The school climate challenge: Narrowing the gap between school climate research and school climate policy, practice guidelines and teacher education policy. Retrieved January 16, 2015, from http://community-matters.org/downloads/school-climate-challenge-policy-paper.pdf

National School Safety Center Review of School Safety Research. (2006). National Center for Education Statistics. Retrieved April 29, 2007, from Academic Search Premier Database: https://www.bjs.gov/content/pub/ascii/iscs06.txt.

Negris-Isik, A., \& Gursel, M. (2013). Organizational culture in successful primary school: Ethnographic study. Educational Science: Theory \& Practice, 13(11), 221-228.

Nishina, A., \& Bellmore, A. (2010). When might peer aggression, victimization and conflict have its largest impact? Microcontexual considerations. Journal of Early Adolescence, 30(1), 5-26. https://doi.org/10.1177/0272431609350928

Olivos, E. M., Jiménez-Castellanos, O., \& Ochoa, A. M. (2011). Bicultural parent engagement: Advocacy and empowerment. New York, NY: Teachers College Press.

Owens, R. (2001). Organizational behavior in education. Boston, MA: Allyn \& Bacon.

Parrett, W. H., \& Budge, K. M. (2012). Turning High-Poverty Schools into High-Performing Schools. Alexandria: Association for Supervision \& Curriculum Development.

Pavlov, I. P. (1927). Conditional reflexes. New York: Dover Publications.

Peterson, K. D., \& Deal, T. E. (1998). How leaders influence the culture of schools. Educational Leadership, 56(1), 28-30.

Petty, R. E., Cacioppo, J. T., Sedikides, C., \& Strathman, A. J. (1988). Affect and persuasion: A contemporary perspective. The American Behavioral Scientist, 31(3), 355-372. https://doi.org/10.1177/000276488031003007

Poza, L., Brooks, M. D., \& Valdez, G. (2014). Entre familia: Immigrant parents strategies for involvement in children's schooling. School Community Journal, 24(1), 119-140.

Priluck, R., \& Till, B. D. (2004). The role of contingency awareness, involvement, and need for cognition in attitude formation. Academy of Marketing Science Journal, 32(3), 329-345. https://doi.org/10.1177/0092070303257646

Renzulli, L. A., Parrott, H. M., \& Beattie, I. (2011). Racial mismatch and school type: Teacher satisfaction, and retention in charter school and traditional public school. Sociology of Education, 84(1), 23-48. https://doi.org/10.1177/0038040710392720

Rhodes, V., Stevens, D., \& Hemmings, A. (2011). Creating positive cultures in a new urban high school. The High School Journal, 94(3), 82-94. https://doi.org/10.1353/hsj.2011.0004

Roberts, J. (1993). Leadership for school culture: knowing the norms, behaviors, and issues. NASSP Bulletin, 77(551), 64-70. https://doi.org/10.1177/019263659307755110

Roney, K., Coleman, H., \& Schlichting, K. A. (2007). Linking the organizational health of middle grades schools to student achievement. NASSP Bulletin, 91(4), 289-321. https://doi.org/10.1177/0192636507310161

Rutter, M., Maughan, B., Mortimore, P., Ouston, J., \& Smith, A. (1979). Fifteen Thousand Hours: Secondary Schools and their Effects on Children. Cambridge, MA: Harvard University Press.

Sadri, G. (2015). Improve employee performance with behavior modification. Talent Development, 69(1), 84-85.

Schaefer, L., \& Clandinin, D. J. (2011). A narrative inquiry into beginning teachers' experiences. Learning Landscapes, 4(2), 275-296. 
Schaefer, L., Downey, C. A., \& Clandini, D. J. (2014). Teacher Education Quarterly, 41(1), 9-27.

Sedivy-Benton, A. L. \& Boden-McGill (2012). Unpacking the effects: identifying school and teacher factors and their influence on teachers' intention to leave the profession. Research in the Schools, 19(2), 75-89.

Sergiovanni, T. (1990). Adding value to leadership gets extraordinary results. Educational Leadership, 7(8), 23-27.

Shaha, S. H., \& Ellsworth, H. (2013). Predictors of success for professional development: linking achievement to school and educator success through on-demand, online professional learning. Journal of Instructional Psychology, 40(1), 19-29.

Shari, A. (2010). Sustainability: Harnessing the collective innovation of all Employees. People and strategy, suppl. Special Issue: Transitioning to the Green. Economy, 33(1), 14.

Sharma, M., \& Bruscum, P. (2013). School -based drug abuse prevention programs in high school students. Journal of Alcohol and Drug Education, 57(3), 51-65.

Sheppard, B., Harley, N., \& Dibbon, D. (2010). Distributed leadership, teacher morale, and enthusiasm: unraveling the leadership pathways to school success: Unraveling the leadership pathways to school success. Retrieved from ERIC Document Reproduction Services. (No. ED509954)

Shimp, T. A. (1991). The role of subject awareness in classical conditioning: A case of opposing ontologies and conflicting evidence. Advances in Consumer Research, 18(1), 158-163.

Shipley, C. J. \& Kleiner, B. H. (2005). Compensation management of commissioned sales employees. Management Research News, 28(2/3), 2-11. https://doi.org/10.1108/01409170510785048

Skinner, B. F. (1948). Superstition in the pigeon. Journal of Experimental Psychology, 38, 168-172. https://doi.org/10.1037/h0055873

Skinner, B. F. (1969). Contingency management in the classroom. Education, 90(2), 93- 101.

Skinner, B. F. (1971). Contingencies of reinforcement. East Norwalk, CT: Appleton Century Crofts.

Smith, T. K., Connolly, F. \& Pryseski, C. (2014). Positive school climate: What it looks like and how it happens. Nurturing positive school climate for student learning and professional growth. Retrieved from ERIC Document Reproduction Services. (No. ED553170)

Somech, A. (2010). Participative decision making in schools: a mediating-moderating analytical framework for understanding school and teacher outcomes. Educational Administration Quarterly 2010, 46(2), 174-209. https://doi.org/10.1177/1094670510361745

Statistics Solutions. (2016). Intellectus Statistics (Version 1.01) [Online computer software]. Retrieved from http://analyze.intellectusstatistics.com/

Stevens, J. P. (2009). Applied multivariate statistics for the social sciences ( $5^{\text {th }}$ ed.). Mahwah, NJ: Routledge Academic.

Stolp, S., \& Smith, S. (1995). Transforming school culture: stories, symbols, values, and the leader's role. Retrieved from ERIC Document Reproduction Services. (No. ED386783)

Sznitman, S. R., Dunlop, S. M., Nakur, P., Khurana, A., \& Roner, D. (2012). Student drug testing in context of positive and negative school climates: Results from a national survey. Journal of Youth an Adolescence, 41(2), 146-155. https://doi.org/10.1007/s10964-011-9658-2

Tabachnick, B. G., \& Fidell, L. S. (2012). Using multivariate statistics $\left(6^{\text {th }}\right.$ ed.). Boston, MA: Pearson.

Tagiuri, R. (1968). The concept of organizational climate. In R. Tagiuri \& Litwin, G. (Eds.), Organizational climate: Explorations of a concept (pp. 1-32). Cambridge, MA: Harvard University.

Taylor, M., Yates, A., Meyer, L., \& Kinsella, P. (2011). Teacher professional leadership in support of teacher professional development. Teaching \& Teacher Education, 27(1), 85-94. https://doi.org/10.1016/j.tate.2010.07.005

Tims, D., \& Meehan, B. T. (1998, May 22). The shooting: Methodical violence leaves 4 dead, 22 hurt. The Oregonian, p. A01. Retrieved November 28, 2015 from LexisNexis Database.

Turid, S. A. (2011). Anti-schoolness in context: The tension between youth project and qualification project. Social Psychology of Education: International Journal, 14(4), 503-518. https://doi.org/10.1007/s11218-011-9153-3

U.S. Department of Education. (2011). Teacher shortage area nationwide list. Washington, DC: Author. Google Scholar.

Versely, A. S., Saklofske, D. H., \& Leschied, A. D. W. (2013). The vital resource: The contribution of emotional intelligence to teacher efficacy and well-being. Canadian Journal of School Psychology, 28(1), 71-89. 
https://doi.org/10.1177/0829573512468855

Vieno, A. Perlins, D. D., \& Smith, T. M. (2005. Democratic school climate an sense of community in school. A multilevel analysis. American Journal of Community Psychology, 36(3), 327-341. https://doi.org/10.1007/s10464-005-8629-8

Wang, M. C., Haertel, G. D., \& Walberg, H. J. (1997). Learning influences, in: H. J. Walberg and G.D. Haertel (Eds) Psychology and Educational Practice (pp. 199-211), Berkley, CA: McCuthan.

Weiss, E. (1999). Perceived workplace conditions and first-year teachers' morale, career choice commitment, and planned retention: a secondary analysis. Teaching and Teacher Education, 15(8), 861-879. https://doi.org/10.1016/S0742-051X(99)00040-2

Weiss, H. B., Lopez, M. E., Kreider, H., \& Chatman-Nelson, C. (Eds.). (2014). Preparing educators to engage families: Case studies using an ecological systems framework ( $3^{\text {rd }} \mathrm{ed}$.). Thousand Oaks, CA: Sage.

Westfall, P. H., \& Henning, K. S. S. (2013). Texts in statistical science: Understanding advanced statistical methods. Boca Raton, FL: Taylor \& Francis.

Wittig, A. F. (2002). Schaum's outline of introduction of psychology. New York: McGraw-Hill.

Wynne, J. (2002b). Teachers as leaders in education reform. Retrieved from ERIC Document Reproduction Services. (No. 462376)

Yaakob, D., Roman, A., \& Yahyan, D. (2015). The types of culture at a high performance of schools and low performance of schools in the state of Kedah. International Education Studies, 8(2), 21-31.

Yariv, E. (2009). The appraisal of teachers' performance and its impact on the mutuality of principal-teacher emotions. School Leadership, 29(5), 445-461. https://doi.org/10.1080/13632430903152302

Zaykowski, H., \& Gunter, W. (2012). Youth victimization: School climate or deviant lifestyles? Journal of Interpersonal Violence, 2(3), 431-452. https://doi.org/10.1177/0886260511421678

\section{Copyrights}

Copyright for this article is retained by the author(s), with first publication rights granted to the journal.

This is an open-access article distributed under the terms and conditions of the Creative Commons Attribution license which permits unrestricted use, distribution, and reproduction in any medium, provided the original work is properly cited. 